\title{
Looking for Irish America in the Memoirs of Mary McCarthy Ellen McWilliams
}

In Mary McCarthy's 1987 memoir How I Grew she looks back at her high school years and her discovery of an academic reference written by her Latin teacher in support of her application to Vassar in 1930. The reference provides her with a retrospective glimpse of her younger self: "Mary McCarthy is a student of quite unusual intelligence. ... I have always found her industrious and pleasant to deal with in the class-room. Mary also has considerable dramatic ability, and played the leading part in the senior play this year. ... She has a strong will and plenty of ambition, and a magnetic and charming personality" (169-70). The letter is an attempt to offer a supportive but realistic impression of McCarthy - the teacher's acknowledgement that the young woman has a strong will and ambition is made safe by the reassurance that she is also industrious, pleasant to deal with, and charming. In How I Grew, McCarthy is keen to put the record straight by including a detailed account of her sexual exploits in the same high school years, one that determinedly punctures the more pious aspects of the Latin teacher's characterization. She pauses to reflect with a mixture of astonishment and glee: "The kindly upright woman was greatly deceived in me. In her worst nightmares that dear Latinist could not have pictured my frequentations: Rex Watson in the woods, Evans Buckley in the hearse, Kenneth Callahan in that eyrie reached by a cat-walk, to say nothing of Forrie Crosby in the Marmon roadster sophomore year, before I even knew her, when I was fourteen" (170, italics in original). Here, McCarthy is surprised, but also pleased, by a dramatic ability of her younger self that is of a different kind to that praised by her teacher - that being her ability to perform the role expected of a Vassar Girl in the making while also 
satisfying her sexual curiosity and following her own desires without censure.

This article explores McCarthy's relationship with life writing and selffashioning and its importance to understanding her writing history and the complicated position that she occupies as an Irish-American woman writer. Read together, McCarthy's memoirs set in motion an elaborate experiment in selfauthorship, an appropriate place to begin in a study concerned with conceptualizations of, and engagements with, Irishness. McCarthy presents something of a conundrum to Irish-American Studies as the broad patterns of her work do not subscribe to IrishAmerican themes but actively resist such categories and outrun the limitations of any potentially limiting compartmentalization. At times, this resistance takes the form of outright hostility while elsewhere she deploys strategies of evasion. However, this should not in any way preclude McCarthy from inclusion in the Irish-American canon, rather she can be read as one of its most vibrantly dissenting voices.

The way McCarthy recalls the failure of her Latin teacher to see beneath the surface is very much in tune with her sustained interest in the gap between selfpresentation and the versions of reality that lie beneath such projected veneers, and it is one that has implications for both McCarthy's experiments with writing a woman's life and a very self-conscious concern with staying one step ahead of any grand narrative of Irish America. In Memories of a Catholic Girlhood (1957), she addresses the same attempts to characterize, categorize, and define Irish America obliquely in her recollection of a formative active writing in which she took up the challenge, aged ten, to write the story of the Irish in America:

When I was ten, I wrote an essay for a children's contest on “The Irish in America", which won first the City and then the State prize. Most of my facts I had cribbed from a series on Catholics in American history that was running 
in Our Sunday Visitor. I worked on the assumption that anybody who was Catholic must be Irish, and then, for good measure, I went over the signers of the Declaration of Independence and added any name that sounded Irish to my ears. (56-7)

This expedient production of a story of Irish America, half-plagiarized, half-invented, makes her less than reverent attitude to her ancestors' history explicitly clear from the start.

In their survey of twentieth-century Irish-American writing, Daniel Casey and Robert Rhodes introduce McCarthy as follows: "Despite her name and background, Irish-Americans do not figure prominently in McCarthy's fiction, and when they do, they are not portrayed sympathetically" (654). They go on to offer an account of the abuse and neglect the orphaned McCarthy and her siblings suffered at the hands of their guardians before concluding: "McCarthy, perhaps understandably, shed Catholicism. And, faced with two strains of 'Irishness' - the too-brief influence of a recklessly extravagant and romantic father as opposed to the grim and tightfisted Irish Americanism of paternal grandparents - it may be equally understandable that she has chosen not to celebrate her Irish heritage" (654).

In Memories of a Catholic Girlhood, McCarthy herself provides clarification regarding her complicated relationship with Irish Catholicism:

I am often asked whether I retain anything of my Catholic heritage. This is hard to answer, partly because my Catholic heritage consists of two distinct strains. There was the Catholicism I learned from my mother and from the simple parish priest and nuns in Minneapolis, which was, on the whole, a religion of beauty and goodness, however imperfectly realized. Then there was the Catholicism practiced in my Grandmother McCarthy's parlor and in 
the home that was made for us down the street - a sour, baleful doctrine in which old hates and rancors had been stewing for generations, with ignorance proudly stirring the pot. (22)

This is one of her clearest articulations of her position, but elsewhere she fiercely glosses various encounters with the same strain of Irish American Catholicism. In How I Grew, she recalls getting chastised at her convent school for precociously mouthing all the parts in a school play and the harsh punishment suffered for drawing attention to herself: "I don't recall the words she used to bring me to my senses, only the derision in her voice - typically Irish, by the way" (21).

While Casey and Rhodes are absolutely correct about the absence of any straightforward celebration of McCarthy's Irish heritage, I am keen to explore what to me seems to be a more complicated relationship with Irishness in her work. In her essay "Mary McCarthy: Too Smart to Be Sentimental” (2008), Sally Barr Ebest argues that McCarthy's relationship with Irish America is more complex than the writer's own protests might suggest:

Mary McCarthy laid the groundwork for subsequent Irish American women writers to develop flawed heroines and to upset stereotypical conventions regarding marriage and motherhood - in sum, to enter the man's world of writing and publishing and succeed on her own terms. In this realm, and despite her denials, McCarthy broke the bounds of Irish American literary conventions by leading her female counterparts into second wave, twentiethcentury feminism. (29)

McCarthy's autobiographies are artful exercises in self-invention that seek to transcend the competing stories of Irishness written into McCarthy's family history. 
And I am interested not just in how she backs away from the problem of Irishness in her work but also how she rescues herself from its limitations - by very assertively pursuing an idea of herself as a self-made public intellectual. The working through of the question or even problem of Irishness in her work is determined in part by the very striking and sustained interest in self-invention in her writing, which is marked by a refusal to be mired in or owned by identity politics of any kind. Especially compelling is how McCarthy's complex feminist and socialist politics interact with her determination to remain outside any totalizing narrative of Irish American identity. Further to this, I suggest that McCarthy's pursuit of an ideal of intellectual sophistication and self-possession in the face of a sometimes hostile reading public, and the role she embraces as an observer of an American intelligentsia in so many of her novels, is a means of recusing and disassociating herself from the more publicly visible scripts historically available to Irish and Irish American women.

The memoirs revisit and rehearse anew key chapters in her life - Memories of a Catholic Girlhood (1957) centers on the formative years of the title, while How I Grew (1987) extends from those girlhood years through to the post-Vassar years, and the carefully titled, posthumously published Mary McCarthy: Intellectual Memoirs, New York 1936-1938 (1993) announces its concern with McCarthy’s public persona and works as a portrait of McCarthy as the public intellectual. Even this shifting of gears between different chapters of her life and return visits to the same events across the autobiographies is telling of an interest in the instability of life writing as a narrative form. Similarly, the semi-autobiographical nature of much of McCarthy's fiction and its direct engagement with or refraction of the concerns that determined her adult life is similarly revealing of an ongoing negotiation with the facts of her lived experience and the processes of fictionalization at the heart of all life writing. 
As Rhodes and Casey suggest, references to McCarthy's Irish heritage and to Irish American life seem at first limited to her early memoirs, but there are a number of glances at and refractions of Irish history and Irish America that surface occasionally, usually in the form of an indirect association or a narrative slight of hand. Alert to the power of dominant histories, McCarthy would have been well versed in the archetypes of Irish American womanhood and treads warily around the same. McCarthy knew exactly what she was up against in writing back to or seeking to protect herself from such dominant types. Her portrait of Catherine Mulcahy, the long-suffering wife of a scheming Joyce scholar in The Groves of Academe (1953), is particularly telling as Catherine appears as a projection of the archetypal Irish Angel in the House, mother to all and helpless pawn in her husband's scheming:

Catherine Mulcahy, moreover, had a womanly, Irish way with her that put the boys at their ease. She was only thirty-one and light on her feet; she had a low, warm encouraging laugh; she remembered first names and nicknames, parents' occupations, where one had gone to school, what one thought of it, where one went for the summer; she was the sort of person who was interested in your birthday, and who could tell you what sign you were born under, your birthstone, and the patron saint of the day. (24)

She appears as an angelic figure who wears her wedding dress and mantilla (19-22) to chaperone the school dances, and keeps the house while her husband attends to the serious business of academia (24).

It is not surprising that the same resistance to such the prescriptive 'womanly, Irish way' of this epitome of maternal self-sacrifice shows itself most forcibly in McCarthy's memoirs. As Claire Lynch reminds us in Irish Autobiography: Stories of Self in the Narrative of a Nation: 
In autobiography, the standard association between the name of the author on the cover and the name of the narrator who guides the reader through the text cuts a ghostly figure in Barthes' formulation.... Whilst these texts remain subject to numerous interpretations, the relevance of the author is unassailable in a way that it is not in the novel. Indeed, publication does not eradicate the author, but rather awards a form of immortality; in autobiography the author is the text. (12)

Memories of a Catholic Girlhood is a thorough excavation of family and cultural history, one that from the beginning demonstrates a wariness of roots, origins, and received histories. McCarthy offers a dramatic version of family history that extends from the family's arrival in North America from Ireland during the Famine years and their various exploits as pirates off the Nova Scotian coast and concludes: "By the time I knew them, the McCarthys had become respectable. Nevertheless there was a wild strain in the family. The men were extraordinarily good-looking, dark and black-browed as pirates, with very fair skin and queer lit-up grey-green eyes, fringed by the McCarthy eyelashes, long, black, and thick" (13). There is a telling tension between members of the McCarthy family as she "knew them" and the risk that she too might have the "McCarthy eyelashes" and the same "queer lit-up grey-green eyes" that is revealing of a desire to excommunicate herself from such family inheritances all the better to study and understand them. The same anxiety about origins and inheritance is followed up in a reading of the social and ethnic hierarchies that organize the family in a wry account of how: "Our family, like many Irish Catholic new-rich families, was filled with aristocratic delusions; we children were always being told that we were descended from the kings of Ireland...” (51). 
Elsewhere, she keenly interrogates other people's readings and misreadings of the Irish, recalling of one of her later lovers: "It delighted him to say that the Irish were the bribed tools of imperialism - he had found the phrase in Marx. I always wondered what it applied to. Marx could hardly have been thinking of Irish cops - New York's finest. In the England of his day, there were no Irish bobbies. But whether or not Marx said it, the phrase amused me and has stuck in my mind" (69). This suspected misattribution is accompanied by other misnomers. She recollects her interest in the Irish roots of the name of an editor at The New Republic from her time working at the magazine: "I learn from my 1978-79 Who's Who? (he was still living then) that he was named Robert Emmett Cantwell. A misnomer, typically Northwestern, for Robert Emmet, the Irish patriot? A spelling error by Who's Who? Or just no connection?" (78). There remains, then, a deliberate ambivalence and uncertainty about what the Irish mean to Americans and yet that isn't to say that she doesn't take the prejudices that lie in wait on account of her Irish Catholic and indeed Jewish ancestry very seriously. In How I Grew, she recalls how: "By senior year I was well aware of having a Jewish grandmother and aware of it - let me be blunt - as something to hide. ... To Ginny's admirers, just out of Yale, it was a rich joke that a girl named Mary McCarthy should be drinking cocktails with them at the country club: Irish were mill workers at the Chase and the Scovill and American brass plants. There was a dirty song - 'Mary Anne McCarthy went out to dig some clams' - though I never understood what was dirty in it...”(217-18).

At such moments, McCarthy fixes her gaze on very real if different kinds of prejudice against different branches of her family trees. This, too, informs the repeated rehearsal of autobiographical plots in so much of her work and the overriding concern with self-authorship in her writing - it serves as a means of 
resisting being read or fixed according to any such prejudiced thinking and so she goes to audacious lengths to avoid being limited to any one narrative of Mary McCarthy.

In "Irish American Modernism" Joe Cleary argues that in the early decades of the twentieth century laying claim to an Irish American identity carried a risk for the aspiring writer: "To do so was to adopt a history that smacked of a benighted peasant or working-class past, or of the sanctimony of middle-class respectability, none of these high cultural heritages" (178). Novelist Dawn Powell reveals the complications of her antipathy towards McCarthy in a colorful characterization of her writing that for all her apparent reservations displays a fervent concern for McCarthy's writing progress. On January 6, 1956, Powell gave vent to her feelings in particularly revealing language:

She has her two manners - her lace-curtain Irish, almost unbelievably genteel lady scholar torn between desire to be Blue Stocking without losing her Ladyship; and then her shanty Irish where she relaxes, whamming away at her characters like a Queen of the Roller Derby, groin-kicking, shin-knifing, bellybutting, flailing away with skates and all arms at her characters and jumping on them with a hoarse whoop of glee when they are felled. (354)

She retreats to the familiar insults of "lace curtain" and "shanty Irish" and her name calling, however satirical the intention, furnishes further evidence for Cleary's claims regarding the problem faced by the Irish American writer in this period.

The complicated dissection of the most imposing and rigid grand narrative that shaped McCarthy's formative years is to be found in Memories of a Catholic Girlhood, which is famous for the fierceness with which she confronts Catholic hypocrisy whilst at the same time mining Catholic tradition for its literary and cultural 
content. The memoir is perhaps best known for its unflinching account of the suffering of McCarthy and her orphaned siblings at the hands of their malicious and negligent guardians.

She throws a number of grenades at any suggestion of nostalgia in the title of the book, and is fearless in excoriating the cozier images of Irish progress in America. If a good deal of McCarthy's fiction and criticism takes just sidelong glances from a safe distance at Ireland and Irish America, Memories of a Catholic Girlhood places her at its very center. However, here too, she insists at all times on destabilizing the progress of her own narrative lest the promises of the title of the book place her too readily in line with tradition. In addition to the book's explicitly critical readings of the world that made her, McCarthy's memoir is, of course, also celebrated for the narrative acrobatics that from the outset ambush the reader with uncertainties.

Her address "To the Reader" at the beginning of the memoir includes an acknowledgement of gaps in memory, a reminder that some names have been changed, and a confession that she really rather wishes she were writing fiction - it is a prologue that is famously keen to hold a mirror up to the narrative processes of the autobiography. She also addresses those correspondents who have written to protest against the book based on their reading of extracts published in advance of its appearance in different magazines and to vilify her for the long shadow her work threatens to cast over Irish American life.

In considering the reception of early published fragments of Memories of a Catholic Girlhood she muses: "Some readers, finding them in a magazine, have taken them for stories. ... The professional writer is looked on perhaps as a 'story-teller', like a child who has fallen into that habit and is mechanically chidden by his parents even when he protests that this time he is telling the truth" $(9$, italics in original). The 
accusations leveled against her by members of the Irish-American community drive her to stage a defense and make a number of clarifications: "In the case of my near relations, I have given real names, and, wherever possible, I have done this with neighbors, servants, and friends of the family, for, to me, this record lays a claim to being historical - that is, much of it can be checked. If there is more fiction in it than I know, I should like to be set right; in some instances, which I shall call attention to later, my memory has already been corrected" (10).

These "corrections" as McCarthy calls them take the form of self-reflexive narrative acrobatics and continue through the book with its Tristram Shandyesque marginalia that offer corrections and clarifications and postscripts and codas that pause to correct and amend. It is a display of narrative pyrotechnics that has left its mark on American prose. McCarthy is given special attention in Dave Eggers's 2000 autobiographical fiction A Heartbreaking Work of Staggering Genius, the preface of which riffs on for almost 40 pages and includes - "Rules and Suggestions for the Enjoyment of this Book" and an "Incomplete Guide to Symbols and Metaphors". Eggers pauses to confess that the title of his book could have been Memories of a Catholic Boyhood, and the postscript of the book, "Mistakes We Knew We Were Making”, gives full release to his predecessor's ghost. If Eggers takes a moment to genuflect to the techniques and devices deployed in Memories of a Catholic Girlhood, McCarthy herself is also happy to acknowledge the influences that give shape to her own memoir. She frames the cruelty of her guardians in terms set by the Victorian novel: "We were beaten all the time, as a matter of course, with the hairbrush across the bare legs for ordinary occasions, and with the razor strop across the bare bottom for special occasions, like the prize-winning. It was as though these ignorant people, at sea with four frightened children, had taken a Dickens novel - Oliver Twist, 
perhaps, or Nicholas Nickleby - for a navigation chart" (57).

George Eliot's Middlemarch (1871-1872) offers a model of self realization of special interest to McCarthy as a woman holding her own in male-dominated intellectual histories. She writes in Ideas and the Novel: "Mr. Casaubon is no Pascal; his "Key to All Mythologies", to which Dorothea plans to devote her young energies, is a figment of his fussy, elderly brain, an "idea" he once had for a multi-volume work which is simply gathering dust in his head. In a sense, this, like Emma, is an education novel: Dorothea has finally grown up when she learns to stop asking her husband about the progress he is making on his master work" (109). McCarthy repeatedly deploys the form of address "To the Reader" familiar in Eliot and other nineteenth century novelists in asides, appeals, and exhortations designed to keep the reader onside. In one of the more improbable salutations to her nineteenth-century realist foremother she revisits the loss of her virginity: "Of the actual penetration, I remember nothing; it was as if I had been given chloroform. ... What I am sure of is a single dreadful, dazed moment having to do with the condom. No, Reader, it did not break. The act is over; he has slid under the steering-wheel and is standing by his side of the car and holding up a transparent little pouch resembling isinglass..." (77-78). The interpolation of this interjection serves the purpose of flagging up the progress of the text as artefact draws heightened attention to her authorial interventions and McCarthy's assertion of agency in owning her own story. McCarthy's candid and playful acknowledgement of the processes of fictionalization at work in writing a woman's life as well as its liberating potential is very much at home with the critical interests of Sidonie Smith's reading of acts of autobiographical writing.. In Subjectivity, Identity and the Body: Women's Autobiographical Practices in the 
Twentieth Century, Smith asks a series of vital questions regarding female appropriation of autobiography:

at the scene of writing, each woman struggles with inherited autobiographical narratives constitutive of the official histories of the subject. When does she take up the sanctities of official narratives and when set them aside? ... What are the pressure points she puts on traditional autobiography as it presses her into a specific kind of autobiographical subject? Where exactly does she find the narrative elasticities and subversive possibilities of the genre? What narrative counterpractices does she import into the text? (23)

The emphasis here on "narrative elasticities" is especially relevant to McCarthy's creation of a palimpsest in the telling of the story of her life, particularly when it comes to the "sanctities of official narratives" and the social and moral codes they import. If there is a sustained refusal of anything that might look like stability in the progress of her narrative and a keen awareness of her own power to project versions of herself, it is because it serves as a useful, self-protecting strategy of evasion that keeps her at a safe distance from limiting archetypes of Irish American womanhood.

It is difficult not to read this process of evasion as linked to the popular image of McCarthy as a professional contrarian. Her changing ideas about socialism and her relationship with feminism and Catholicism are marked by contradictions she seemingly embraces. In The Banshees: A Literary History of Irish American Women Writers (2013) Sally Barr Ebest suggests “Although McCarthy rejected the Catholic Church, she was unable to shake its tenets - a tendency characteristic of most Irish American women writers of this period. ... Despite her anti-feminist statements, her characters represent conflicting tensions as they are pulled between the desire for sexual and intellectual freedom and their internalized Catholic sense of guilt" (73). In 
contrast to Barr Ebest's careful weighing up of these complexities, the other image of McCarthy as a kind of "Contrary Mary" is one too often deployed as a diminishing tactic.

If McCarthy's life writing is marked by turning away from received scripts of who she might be in the world, it is also characterized by an enthusiastic embracing of the freedom and authority conferred upon the intellectual. The idea of the intellectual looms large from the beginning of How I Grew. The early chapters of the narrative are dedicated to McCarthy's high school and college years and preparation for her apotheosis into New York Intellectual Circles: "I was born as a mind during 1925, my bodily birth having taken place in 1912” (1). Throughout How I Grew, McCarthy appears as a Caliban figure and books represent empowerment and a final break from the cruelty of her guardians: "When I was rescued by my Protestant grandfather from the evil spell of the house on Blaisdell Avenue, one of the immediate effects was the opening up of libraries to me" (23). From this point, she offers a full account of her education courtesy of her uncle's bookshelves and gaining access to the public library offers an extension of this new freedom and is a defining moment in the fashioning of her young adult identity: "I remember the feeling of power conferred on me by the small, ruled piece of cardboard still empty except for my name typed at the top and my signature below" (30).

Her high school years are remembered for her growing awareness of and interest in the abstract figure of the "intellectual" and the freedom and liberty to pursue a life unfettered by the limits of convention:

It was in public high school that I became conscious for the first time of a type of person that we would now call an intellectual. In those days the word for such people collectively was "intelligentsia," borrowed from the Russian and 
scarcely used any more, as though the Bolshevik Revolution, in eliminating the social grouping, had consigned the term to "the ashcan of history" - a favorite receptacle. "Intelligentsia" had included bohemians - artists and musicians, people like Pasternak's parents - as well as narodniki, nihilists, teachers, doctors, sometimes combining several of these vocations in one person as in Turgenev's Bazarov. It was the enlightened class in society. The characters typically found in Chekhov - army officers, country doctors, small landowners fond of musing on large ideas, students - all belong to the intelligentsia, whatever their occupation or lack of it. (31-32, italics in original)

The emphasis on "enlightenment" is a direct contradiction of McCarthy's experience as a prisoner of her aunt and uncle's mean and narrow vision and her rule-bound existence under their watch. Her involvement in school and college publications and perhaps even her later work for periodicals such as The Nation, The New Republic, and key role in the relaunch of Partisan Review in the 1930s might all be traced back to this formative experience of identifying the life of the intellectual as a liberal safe harbor from the impoverishment of her early years.

She recalls a moment of recognition as a young woman:

Today journalists are not considered intellectuals. But in 1925, in the West, high-school and college newspapers seemed secure stepping-stones to literary and intellectual fame. ... Jack London, Frank Norris, Dreiser, Mencken, Ben Hecht, Burton Rascoe had blazed the trail to the city room or afield in the correspondent's tent - in Seattle we did not know yet of "Bunny" Wilson and Hemingway, who had been making their start in the same way. (35) 
Two of those named would play a key role in McCarthy's own life as a New York intellectual as she sent her early work to Mencken and was encouraged by his response and would later marry the eminent American critic Edmund "Bunny" Wilson, although she remains coy about both associations in recounting her fascination with the very world within which she would later occupy a distinctive and formidable position.

During her University years at the beginning of the early 1930s McCarthy was a beneficiary of the carefully regulated educational style of Vassar College, an initiation into the sorority so vividly dramatized in The Group:

A good deal of education consists of un-learning - the breaking of bad habits as with a tennis serve. This was emphatically true of a Vassar education: where other colleges aimed at development, bringing out what was already there like a seed waiting to sprout, Vassar remade a girl. Vassar was transformational. No girl, it was felt, could be the same after Kitchel's English or Sandison's Shakespeare, to say nothing of Lockwood's Press. (203, italics in original)

In How I Grew, she casts her teachers and a select number of her fellow students as members of an intelligentsia in their own right and her Vassar experience was clearly her first opportunity to test her own ambitions amongst an intellectual elite.

McCarthy's concern with the public visibility of the intellectual is a palpable and recurring concern in her fiction, as well as in her life. Amongst the character types encountered by Margaret Sargent, a version of the young McCarthy, in her first work of fiction, The Company She Keeps (1942), including the "The Genial Host" and the "The Man in the Brooks Brothers Shirt", appears a satirical "Portrait of the Intellectual as a Yale Man": 
The year he came down from Yale (where he could have been Bones but wouldn't), he was worried about Foster and Ford and the Bonus Marchers and the Scottsboro Boys. He had also just taken a big gulp of Das Kapital and was going around telling people about how he felt afterwards. ... Later that evening Al remark to his wife that maybe it would be a good idea (didn't she think?) to lay in a stock of durable consumers' goods - in case, oh, in case of inflation, or revolution, or anything like that.... This was the phenomenon known as the dissemination of ideas. (128)

Her second novel, The Oasis (1949), amplifies her satirical reading of the New York Intellectual, set in a utopian colony and drawing heavily on the circles that McCarthy moved in while A Charmed Life (1955) is set in a community of artists and writers. Her own intellectual achievements were those of the polymath. McCarthy's biographer Carol Brightman compiles a list of McCarthy's professions. She begins by noting that in the 1930s

An intellectual young woman had to be careful to remain alert to her status as interloper, particularly if she didn't care to be mistaken for one of the boys, or appear masculine, which Mary emphatically was not. Even more dangerous was to seem to have it all, when one was in reality only at the beginning of a polymorphous career as a femme fatale, a critic of theatre and literature, as well as of society, a satirist and novelist, an art historian, a war correspondent, and a memoirist of the first rank. (148)

This was to be a dilemma not easily resolved - Elaine Showalter in "Laughing Medusa: Feminist Intellectuals at the Millennium” writes:

The female intellectual is far from dying, but she is camouflaged by her 
gender. Indeed, the category of the intellectual has been almost as invisible to feminists as to male theorists. The women's movement tends to be embarrassed and defensive about its intellectuals, whether because of the activist values and anti-elitist pressures of feminist thought or because discussions of intellectuals have been so sterile, dispassionate and disembodied. (132)

She goes on to identify categories by which the woman intellectual has historically been categorized: Cassandra, The Feminist Medusa, The Dark Lady. She concludes: "The idea of the Dark Lady as the only girl in the gang, fighting off competition from her rivals, is now being preserved by Camille Paglia, who has compared her 'hot eye' to Mary McCarthy's cold one, and gone after Sontag in a 'one-sided feud'”( 137).

Showalter's characterization of McCarthy as a lone woman amongst male intellectuals is dramatized in the table of contents of the political magazine Partisan Review. A leading figure in the relaunch of Partisan Review in 1937, McCarthy took her place alongside James T. Farrell, Wallace Stevens, Edmund Wilson, and Pablo Picasso in the first issue. Hugh Wilford in The New York Intellectuals: From Vanguard to Institution (1995) paints a vivid picture of how central McCarthy was to New York intellectual life in the 1940s and 1950s, a welcome corrective to a sometimes unhelpful fascination with the granted colorful and fascinating details of her private life, her complicated marriages, and forays into public warfare with other notable thinkers and critics of the day. Sabrina FuchsAbrams's Mary McCarthy: Gender, Politics, and the Postwar Intellectual (2004) offers an illuminating exposure of the politically engaged McCarthy and opens with a precise account of her changing political affiliations from the 1930s to the 1960s: 
Mary McCarthy is not in but of the world of New York intellectuals, a group of scholars and critics associated with the anti-Stalinist journal, Partisan Review, in the 1930s and 40s. As a Catholic woman from the Northwest, she remains on the periphery of the largely Jewish, male-dominated New York intellectual scene. This marginalized identity shapes McCarthy's satiric vision and makes her a consummate critic of liberalism from within. Neither a Marxist nor a proponent of literary modernism, McCarthy scrutinizes the movement among intellectuals from Marxism in the thirties toward revisionist liberalism and liberal anti-Communism in the fifties. From her tendency toward anarcho-pacifism in the forties to her stand with the non-Communist left in the fifties and her outspoken opposition to the Vietnam war in the sixties, McCarthy stands apart from many of her contemporaries. ... Through the art of satire, McCarthy questions certain liberal assumptions and redefines the role of the intellectual and the place of the woman intellectual in postwar American culture. (1)

McCarthy was, then, with Fuchs Abrams's contextualizing history in mind, an interloper in an already marginalized group.

McCarthy's insistence on reading volatility or contrariness (a crime charged against her by so many of her critics) as a positive weapon in life's artillery can be traced back to a formative moment in her childhood, one that she pauses to celebrate in Memories of a Catholic Girlhood, which includes a scene in which an 11 year old McCarthy is indicted by a teacher for being 'Just like Lord Byron, brilliant but unsound' (83). She recalls: "I had never felt so flattered in my life. ... Madame Barclay's pronouncement, which I kept repeating to myself under my breath, had for us girls a kind of final and majestic certainty" (83). What emerges from McCarthy's 
supremely self-conscious experiments in life writing and self-fashioning as an intellectual might be characterized as contributing to the reclamation of a missing history of sophistication in the story of Irish women in America - read together her memoirs represent a very determined pursuit of the story of her own intellectual coming of age, one that is rehearsed over and over in her fiction and life writing.

Ultimately, with regards to her relationship with Irish America, the politics of McCarthy's life writing remains a politics of resistance. Her first work of fiction was published in 1942 the same year the New York City Irish Echo reported on the particular success of the annual Irish Feis held at Fordham University's Rose Hill Campus in the Bronx in language full of wistful nostalgia of a kind that would have been at home in the work of popular Irish American Celticist Donn Byrne:

Despite the threatening weather, the 1942 Feis sponsored by the United Irish Counties Association was brought to a successful conclusion on the beautiful campus of Fordham University last Sunday. For the most part everything panned out as per the blue print, save for the speech-making, which was about one hour too long.

Truly was it an Irish day in New York, and fitting too that so many sons and daughters of the Gael should tread the sod of Fordham campus where so many of Ireland's illustrious sons and daughters have trod since the University was first opened a little over a century ago. (48)

There's a telling footnote, one that appears rather late in the account: "While handing out bouquets, let us not forget the mothers of the children whose contribution to the success of the Feis was great indeed" (48). It is safe to assume that Mary McCarthy, herself a mother since 1938, did not attend the Fordham Feis in 1942. 1942 was also the year in which she published The Company She Keeps, a template for the coming 
of age of the publicly visible intellectual woman. It is the ur-text of the narrative that would become one of the dominant preoccupations of her writing life, and so on that June day she was otherwise engaged inventing a new and heretofore untold story in the annals of Irish America. 


\section{Works Cited}

Barr Ebest, Sally. "Mary McCarthy: Too Smart to Be Sentimental." Too Smart to Be

Sentimental: Contemporary Irish American Women Writers, edited by Sally Barr

Ebest and Kathleen McInerney, U of Notre Dame P, 2008, pp. 27-51.

Barr Ebest, Sally. The Banshees: A Literary History of Irish American Women

Writers. Syracuse UP, 2013.

Brightman, Carol. Writing Dangerously: Mary McCarthy and her World. Harcourt Brace, 1992.

Casey, Daniel J. and Rhodes, Robert E. "The Tradition of Irish-American Writers:

The Twentieth Century." Making the Irish American: History and Heritage of the

Irish in the United States, edited by in Marion R. Casey and Joe Lee, New York UP, 2006, pp. 649-62.

Cleary, Joe. "Irish American Modernisms." The Cambridge Companion to Irish

Modernism, edited by Joe Cleary, Cambridge UP, 2014, pp. 174-92.

Eggers, Dave. A Heartbreaking Work of Staggering Genius. Picador, 2000.

Fuchs Abrams, Sabrina. Mary McCarthy: Gender, Politics, and the Postwar

Intellectual. Peter Lang, 2004.

Lynch, Claire. Irish Autobiography: Stories of Self in the Narrative of a Nation. Peter Lang, 2009.

McCarthy, Mary. How I Grew. Weidenfeld \& Nicolson, 1987.

---. Ideas and the Novel. Harcourt, Brace, Jovanovich, 1980.

---. Mary McCarthy: Intellectual Memoirs, New York - 1936-1938. Harvest, 1993.

---. Memories of Catholic Girlhood. Penguin, 1963. 
---. The Groves of Academe. Panther, 1964.

Powell, Dawn. The Diaries of Powell 1931-1965, edited by Tim Page, Steerforth Press, 1995.

Showalter, Elaine. "Laughing Medusa: Feminist Intellectuals at the Millennium." Women: A Cultural Review, vol. 1, no. 2, 2000, pp. 131-138

Smith, Sidonie. Subjectivity, Identity, and the Body: Women's Autobiographical Practices in the Twentieth Century. Indiana UP, 1993.

Wilford, Hugh. The New York Intellectuals: From Vanguard to Institution.

Manchester UP, 1995. 